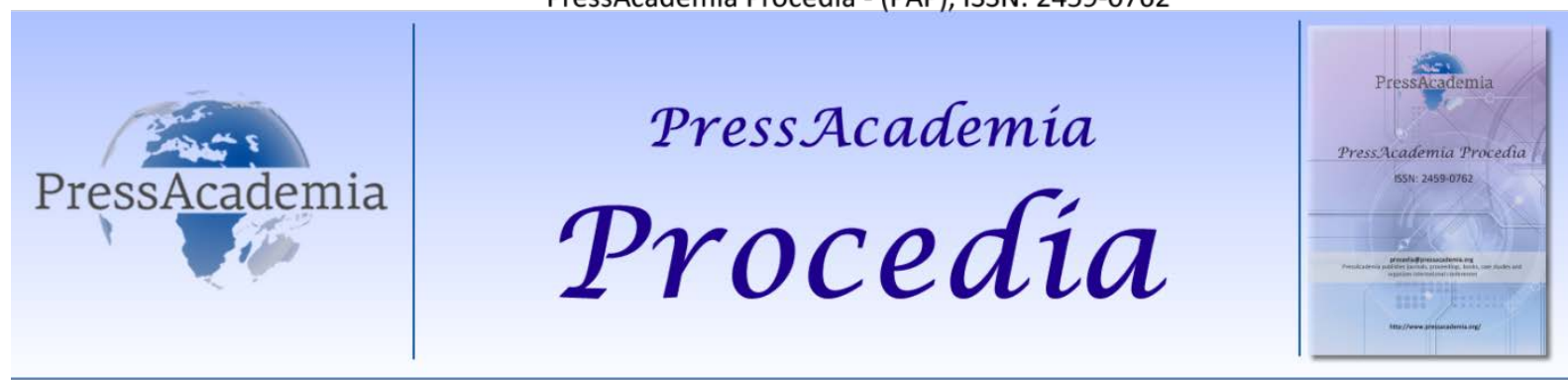

Global Business Research Congress (GBRC), May 26-27, 2016, Istanbul, Turkey.

\title{
IAS 18 REVENUE STANDARD IN FACTORING COMPANIES AND AN APPLICATION
}

\section{DOI: 10.17261/Pressacademia.2016118681}

\author{
Huseyin Mert ${ }^{1}$, Ece Bas ${ }^{2}$ \\ ${ }^{1}$ Okan Üniversitesi, huseyin.mert@okan.edu.tr \\ ²okan Üniversitesi, ece.bs@hotmail.com
}

\begin{abstract}
The term "Factoring Operations" stand for a financial service which guarantees and performs collection of debt that emerges from domestic or international forward sales of the applicant company. These Operations start off with the internal assessment and acceptance procedures of the debt, which leads to the factoring company to takeover the debt collection role. In this context, the revenue constituents obtained by the factoring company should be booked in compliance with the Turkish Accounting Standards No:18.. Since IAS 18 "Revenue" requires the revenue to be booked at fair value, late interest revenues which result from forward sales need to be differentiated from the sales revenue and booked as interest revenue. This paper examines revenue bookkeeping methods according to accounting standards by considering the factoring sector.
\end{abstract}

\section{FAKTORING IŞLETMELERINDE TMS 18 “HASILAT” STANDARDI VE BİR UYGULAMA}

\section{ÖZET}

Faktoring işlemleri, Faktoring şirketinden talepte bulunan müşteriye ait yurtiçi ve yurtdışı mal ve hizmet satışlarından doğan vadeli alacakların kendi değerlendirme ve kabul süreçlerinden geçirerek devralmasıyla başlayan ve satın alınan alacakların vadeleri geldiğinde yeni sahibi olarak kendisi tarafından tahsilatının yapılmasıyla tamamlanan garanti ve tahsilat hizmetlerinin bir veya birkaçının sunulduğu finansal bir üründür. Bu kapsamda Faktoring Şirketlerinin elde ettiği gelir getirici unsurlarının 18 Nolu Türkiye Muhasebe Standardı çerçevesinde (TMS 18) muhasebe kayıtlarının yapılması gerekmektedir. TMS 18 "Hasılat" standardına göre hasılat tutarının gerçeğe uygun değer ile muhasebeleştirilmesi gerektiğinden, vadeli işlemlerde ortaya çıkan satış bedeli içerisinde yer alan vade farklarının satış bedelinden ayrıştıııması ve faiz geliri olarak muhasebeleştirilmesi gerekmektedir. Bu çalışmada muhasebe standartlarına göre hasılat tutarlarının muhasebeleştirilme yöntemleri incelenmiş, faktoring sektörü dikkate alınarak konu değerlendirilmeye çalışımıştır.

Anahtar Kelimeler: Hasılat, TMS Hasılat, hasılat ve faiz tespit yöntemleri

JEL Kodları: M41, M42

\section{GíRiş}

Faktoring işlemi, mali sektörün en dinamik birimi olan bankalar tarafından Türkiye'de ilk defa 1988 yılında gerçekleştirilmiştir. Dünyada faktoring sektörü yurt içi faktoring işlemi ile başlamış iken ülkemiz yurt dışı faktoring yöntemi ile sektöre adım atmıştır. 
31.12.2015 tarihi itibarıyla 63 şirketten oluşan Türkiye Faktoring Sektörünün toplam aktifleri 94 milyar 591 milyon TL'lik büyüklüğe sahiptir. Ekonominin en önemli aktörlerinden biri olan faktoring işletmelerinin muhasebe kayıtlarının ve finansal tablolarının karşılaştırılabilir olması gerekmektedir. Bu sebeple muhasebe alanında ülkeler arası farklılıkları ortadan kaldırmak amacıyla uluslararası muhasebe standartları oluşturulmuş olup uygulanmaya başlanılmıştır.

Bu çalışma hedef müşteri kitleleri, sundukları hizmetler ve farklı iş stratejileriyle çalışan faktoring şirketlerinin gelir getirici unsurlarının 18 Nolu Türkiye Muhasebe Standardı çerçevesinde (TMS 18) muhasebe kayıtlarının nasıl yapılması gerektiği açıklanmak amacıyla yapılmıştır.

Yapılan izahatlar ışığında öncelikle faktoring işleminin işleyişi detaylıca açıklanmış olup TMS 18 "Hasılat" standardına göre hasılat tutarının gerçeğe uygun değer ile muhasebeleştirilerek, vadeli işlemlerde ortaya çıkan faiz gelirinin tek düzen muhasebe sisteminde nasıl muhasebeleşeceği ve faktoring sektörü ele alınarak nasıl uygulanabileceği tespit edilmeye çalışılmıştır.

\section{FAKTORING IŞLEMININ TANIMI VE IŞLEYişi}

\subsection{Faktoring İşleminin Tanımı Ve Açıklamaları}

Dünyada bankacılık işlemlerinden sonra en yaygın finansman yöntemi olarak yer alan faktoring işlemleri; garanti, tahsilat ve finansman hizmetlerinin sunulduğu bir finansal üründür. Faktoring işletmelerinden hizmet talebinde bulunan müşteri firma, yurtiçi ve yurtdışı mal ve hizmet satışlarından doğan vadeli alacakların faktoring işletmelerine devrederek daha kolay ve hızlı finansman sağlarlar.

6361 sayılı Finansal Kiralama, Faktoring ve Finansman Şirketleri Kanununun 38.maddesine göre Faktoring sözleşmesi; mal veya hizmet satışından doğmuş fatura ile tevsik edilen alacaklar ile Kurulca belirlenen usul ve esaslar çerçevesinde tevsik edilebilen mal veya hizmet satışına bağlı doğacak alacakları devir almak suretiyle, faktoring şirketinin müşterisine sağladığı tahsilat, borçlu ve müşteri hesaplarının tutulmasının yanı sıra finansman veya faktoring garantisi fonksiyonlarından herhangi birini ya da tümünü içeren sözleşmedir (Finansal Kiralama, Faktoring ve Finansman Şirketleri Kanunu, 38). Kanunla, faktoring işleminin çerçevesi uluslararası uygulamalara paralel olarak yeniden düzenlenmiş ve faktoring, işletmelerin finansal ihtiyaçlarını hızlı, esnek ve güvenilir şekilde karşılayabilecekleri enstrüman haline getirilmiştir (Sağlam, 2013). Sağlam (2013)'te vurgulandığı gibi faktoring sözleşmelerinde üç taraf bulunmaktadır;

- $\quad$ Factor (Faktoring Şirketi): Müşteri firmaya ait yurtiçi ve yurtdışı mal ve hizmet satışlarından doğan vadeli alacakların kendi değerlendirme ve kabul süreçlerinden geçirerek devralmasıyla başlayan ve satın alınan alacakların vadeleri geldiğinde yeni sahibi olarak tahsilatını yapan firma.

- Müşteri (Alacaklı Firma, Satıcı): Faktoring işlemini talep eden ve alacaklarını faktoring şirketine devreden firma.

- Borçlu (Alıcı): Alacaklı olan firmaya borcu olan işletme.

Faktoring işletmelerinin sunduğu hizmetler ise; faktoring işletmesine temellük edilen alacakların belli bir kısmının vadesinden önce müşteri firmaya ödenmesi "Finansman", faktoring sözleşmesi çerçevesinde alıcının ödememe riskinin faktoring işletmesi tarafından yüklenilmesi "Garanti", faktoring işletmesi tarafından alacağın vadesinde takibi ile tahsilatının yapılması ile "Tahsilat" olarak üç başlık altında toplanır.

\section{FAKTORING IŞLEMININ TÜRLERI VE AÇIKLAMALARI}

\subsection{Rücu Edilebilme Durumuna Göre:}

- $\quad$ Rücu edilemez faktoring (Gayrı kabilirücu, Geri dönüşsüz faktoring): Faktoring işletmesinin teminat fonskiyonunu kabul ederek alacağın tahsil edilememe riskini üstlenmesidir. Bu şekilde faktoring işletmesi müşteriye bu riski rücu edemeyecektir.

- Rücu edilebilir faktoring (Kabilirücu, Geri dönüşlü faktoring): Alacağın ödenmeme riskinin faktoring işletmesi tarafından üstlenilmediği, ilgili işletmenin yalnızca finansman ve tahsilat taleplerine destek verdiği faktoring türüdür. 


\subsection{Faktoring Hizmetlerinin Yürütüldüğü Yere Göre:}

- Yurtiçi Faktoring: Alacakı ve borçlu firmanın aynı ülke sınırları içerisinde faaliyette bulunduğu faktoring türüdür.

- Yurtdışı Faktoring: Aynı ülke sınıları içerisinde faaliyette bulunmayan alacaklı ve borçlu firmanın yapmış olduğu ihracat ve ithalatı kapsayan satışların faktoring işletmesi tarafından tahsilinin ve takibini içeren faktoring türüdür.

\section{3 Ödeme Zamanına Göre:}

- Ön ödemeli Faktoring: Faktoring işletmesi müşteri firmadan alacaklarını devralır ve belli bir kısmını vadesi gelmeden ödemesini içeren faktoring türüdür.

- Vadeli Faktoring: Ön ödemeyi içermeyen bir faktoring türüdür. Vadeli faktoring seçeneğinde faktoring işletmesi; müşterisine sadece tahsilat ve garanti hizmetlerini sunar, finansman hizmeti sağlamaz.

\subsection{Bildirim Durumuna Göre:}

- Bildirimli Faktoring: Müşteri firmanın vadeli satışlarından doğan alacaklarını faktoring işletmesine devrettiğini borçlulara bildirdiği faktoring türüdür.

- Bildirimsiz Faktoring: Müşteri firmanın vadeli satışlarından doğan alacaklarını faktoring işletmesine devrettiğini borçlulara bildirmediği, borçlulara gönderdiği faturalarda temlik notuna yer vermemesi, tahsilatları müşteri firmanın bizzat kendisinin yapması faktoring şirketinin ise sadece garanti ve finansman hizmetinin verildiği faktoring türüdür.

\subsection{Diğer}

- Tam servis faktoring: Bu uygulamada müşteri firmaya bir faktoring işleminde gerçekleşebilecek olan tüm fonksiyonlar (Garanti, Tahsilat, Finansman) faktoring şirketi tarafından sunulur.

- Toplu İskonto: Müşteri firmanın mal ve hizmet satışlarından doğan ve elinde bulunan kısa vadeli alacaklarının faktoring işletmesi tarafından satın alınarak müşteri firmaya finansman sağlama yöntemidir. Bu yöntemde işlem rücu etme esasına dayanır ve borçlulara bildirimde bulunulmaktadır. Bu sebeple faktoring işletmesi borç tahsilatından sorumlu değildir.

- Fatura i̇skonto: Faktoring işletmesine başvuran müşteri firmanın tahsilat sıkıntısının bulunmaması ve riski minimize ederek korunmaya ihtiyacı bulunmuyor ise bu firmaya sadece finansman kolaylı̆ı sağlanmaya çalışıır. Bu yöntemde borçlulara bildirimde bulunulmamaktadır.

- Aracılı Faktoring: Alacaklı olan firmaya borcu olan işletmenin borcunu ödememe riskine karşı korunma ile finansman hizmetinin sağlandığı bu yöntemde müşteri firma faktoring işletmesinin acentesi görevini almakta olup tahsilat takibini de Faktoring işletmesi adına yapması yöntemini ifade etmektedir.

- Toptan Faktoring (Bulk Faktoring): Ufak tutarlardaki birçok satışın birleşimi ile oluşan alacak haklarının faktoring işletmesine devredilir, faktoring işletmesi de finansman ve tahsilat işlemlerini belirli aralıklarla yaparak işlem yükünü azaltır. 


\subsection{Faktoring İşleminin Uygulanması}

Faktoring hizmetinden yararlanmak isteyen satıcı firmanın faktoring şirketine başvurarak gerekli bilgi ve belgeleri vermesiyle ilk adım atılmış olur. Faktoring şirketi gerekli incelemeleri yaptıktan sonra satıcı firmaya teklifini sunar. Bu teklifinde yapacağı hizmetleri, alacağı komisyon ve ücretleri bildirir. Faktoring şirketi ile satıcı firma arasında sözleşme imzalanır.

\section{Şekil 1: Faktoring Süreci}

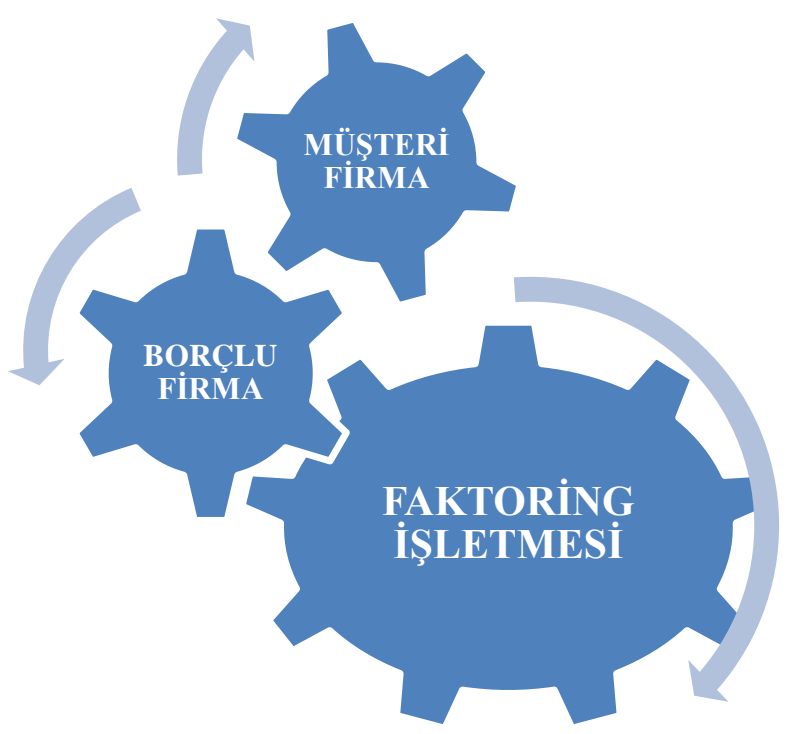

Müşteri, mal veya hizmet satışından doğmuş /doğacak alacaklarını faktoring işletmesine yazılı bildirir. Fatura ve / veya alacağı tevsik eden evrakın bir kopyasını da faktoring işletmesine gönderir. Müşteri, alacak bildirim yazısı ve alacağı tevsik eden evrakla birlikte, ödeme vasıtalarını (çek, senet ve benzeri) faktoring işletmesine usulüne uygun olarak devir ve teslime yükümlüdür. Faktoring işletmesi yani faktor ihtiyaç halinde müşteriden ek bilgi ve belge talep etme hakkına sahiptir. Müşterinin talebine göre faktoring sözleşmesi çerçevesinde faktor tarafından ön ödeme yapılabilir. Faktoring şirketi dilerse, kendisine temlik edilen alacakların tahsilatını beklemeksizin kullandırdığı ön ödeme ve ferilerini (faiz, ücret, komisyon) geri çağırabilir ya da müşteri vadeyi beklemeden de alacak tutarını ödeyebilir. Temlik konusu alacakların tahsilatı şu şekillerde gerçekleşebilir:

- Alacak, vadesinde borçlu tarafından faktoring kuruluşuna nakit veya diğer şekillerde (çek, senet, poliçe vb.) ödenir,

- Müşteri tarafından faktore devir ve teslim edilen ödeme vasıtaları (çek, senet, poliçe vs.) tahsilatı ile ödenir,

- Faktor tarafından müşteriye tahsilat yetkisi verilmiş ise bu yetkiye istinaden müşteri tarafından borçludan tahsil edilerek faktore ödenir,

Faktoring ücreti, komisyonu, masrafları faktor tarafından, yapılan anlaşmaya göre, Müşteri ve/veya borçludan tahsil edilebilir. Faktor, alacakların tahsilatını müteakip , müşteri ile yaptığı anlaşmaya göre, müşterinin borçları düşüldükten sonra, faktoring işlemlerinden artabilecek bakiyeyi müşteriye öder (Faktoring Derneği, 2016). Faktoring Derneği'nin de vurguladığı üzere faktoring şirketinden talepte bulunan müşteriye ait yurtiçi ve yurtdışı mal ve hizmet satışlarından doğan vadeli alacakların kendi değerlendirme ve kabul süreçlerinden geçirerek devralmasıyla başlayan ve satın alınan alacakların vadeleri geldiğinde yeni sahibi olarak kendisi tarafından tahsilatının yapılmasıyla tamamlanan garanti ve tahsilat hizmetlerinin bir veya birkaçının sunulduğu finansal bir üründür. 


\subsection{Faktoring Maliyeti}

\subsubsection{Faktoring Komisyonu (Yönetim Bedeli)}

Faktoring işletmesinin müşteri firmaya sunduğu garanti, finansman ve tahsilat hizmetleri karşılığında alacak tutarı üzerinden bir hizmet komisyonu bir başka deyişle faktoring komisyonu tahakkuk eder. Söz konusu komisyon tutarı devralınan alacağa ilişkin risk ölçümlemesine ve hizmet türüne göre değişiklik gösterebilir.

\subsubsection{Faktoring Ücreti (Faiz, Finansman Maliyeti)}

Müşteri firmanın talebi doğrultusunda verilen finansman hizmeti için, kullanılan finansman tutarı üzerinden kullanım süresi kadar olan vade ve/veya risk durumları baz alınarak yansıtılan finansman masrafı faktoring işletmesi tarafından tahakkuk ettirilmektedir.

\subsubsection{Banka Sigorta Muamele Vergisi (BSMV)}

İç piyasadan doğan alacakların faktoring işlemine konu olması sonucu oluşan ücret ve komisyonlar BSMV'ye tabidir. Buna karşılık ihracat faktoring işlemlerinde ise faktoring ücret ve komisyonları BSMV 'den muaftır.

\subsection{Faktoring İşlemlerinin Vergi Kanunları Karşısındaki Durumu}

\subsubsection{Borçlar Kanunu}

Müşteri firmanın faturaya bağlı alacaklarının devir ve temliki, Borçlar Kanunu'nda düzenlenmiş bulunan 183. Maddede "Kanun, sözleşme veya işin niteliği engel olmadıkça alacaklı, borçlunun rızasını aramaksızın alacağını üçüncü bir kişiye devredebilir." denmektedir ve buna ilaveten 184. Madde de "Alacağın devrinin geçerliliği, yazılı şekilde yapılmış olmasına bağlıdır.Alacağın devri sözü verme, şekle bağlı değildir" ifadesi yer almaktadır (Borçlar Kanunu,183 ve 184). Alacağın temlikinin Kanunda vurgulanan hükümler çerçevesinde yapılması halinde, faktoring işlemleri alacağın temliki niteliğine kavuşur. Kanun alacaklının yani müşteri firmanın, alacağını üçüncü bir şahsa devretmesine izin vermektedir. Alacağın devrinde alacağın talep hakkı devredilmekte dolayısıyla yeni bir alacak doğmamaktadır. Yapılan izahatlar ışığında anlaşılıyor ki alacağın tahsil edilme sorumluluğu tamamen alacak hakkını devir alana geçer. Bu noktada borçlu temlik sözleşmesinin dışında yer almaktadır.Alacağın temlikinin geçerli olabilmesi için temlik sözleşmesinin 184. Maddede vurgulandığı üzere yazılı yapılması gerekmektedir.

\subsubsection{Katma Değer Vergisi (KDV)}

3065 sayılı Katma Değer Vergisi Kanununun 17-4/e maddesinde yer alan "(4842 sayılı Kanunun 23'üncü maddesiyle değişen bent Yürürlük; 01.07.2003) Banka ve sigorta muameleleri vergisi kapsamına giren işlemler ve (5766 sayılı Kanunun 12/a maddesiyle değişen ibare Yürürlük; 01/08/2008) sigorta aracılarının sigorta şirketlerine yaptığı (32) sigorta muamelelerine ilişkin işlemleri ile Kurumlar Vergisi Kanununun 7 nci maddesinin (24) numaralı bendinde belirtilen kurumların kredi teminatı sağlama işlemleri," ifadesinde vurgulandığı üzere BSMV kapsamına giren işlemler Katma Değer Vergisinden istisnadır. Kanundan anlaşılacağı üzere faktoring işlemleri de KDV'ne tabi değildir (KDV, 17-4/e).

\subsubsection{Damga Vergisi ve Harçlar Kanunu}

488 no lu Damga Vergisi Kanuna ekli (2) sayılı tablonun "IV-Ticari ve Medeni İşlerle İlgili Kağıtlar" bölümünün 20 nci maddesinde, faktoring şirketlerinin müşterileriyle yaptıkları faktoring sözleşmeleri ile bu sözleşmelere ilişkin olarak düzenlenen diğer kağıtların damga vergisinden istisna edildiği belirtilmiştir (Damga Vergisi, Ekli(2) sayılı tablo, 20).

Damga Vergisi kanununda özel istisna maddesi olmasına rağmen yurt dışı (ihracat) faktoring işlemlerinde için T.C. Hazine Müsteşarlığının 23.12.1999 tarih ve 99/13812 sayılı kararname eki ihracatı teşvik kararına dayanılarak çıkarılan 05.12.2008 tarih ve 27075 sayılı Resmi Gazetede yayınlanan 2008/6 ihracat, Transit Ticaret, İhracat Sayılan Satış ve Teslimleri ile Döviz Kazandırıcı Hizmet ve Faaliyetlerde Vergi, Resim ve Harç İstisnası Hakkında Tebliğin 4.cü maddesi uyarınca,

b-) Ihracatla ilgili işlem yapan bankaların (Türkiye Cumhuriyet Merkez Bankası dahil), faktoring şirketlerinin, sigorta şirketlerinin, noterlerin ve diğer kuruluşların ihracat, ihracat sayılan satış ve teslimler ile döviz kazandırıcı hizmet ve faaliyetlerle ilgili olarak yapmış oldukları bütün hizmet ve muameleler (Türk Eximbankın ihracat kredi 
sigortası/garantisi ile ilgili işlemleri dahil) dolayısıyla kendi lehlerine her ne nam ile olursa olsun nakden veya hesaben aldıkları paralar ve kambiyo işlemleri,

c) ihracat karşılığı yapılacak her türlü ödemeler, ihracat, ihracat sayılan satış ve teslimler, döviz kazandırıcı hizmet ve faaliyetler ile transit ticaretle ilgili işlemler ve bu işlemler sebebiyle düzenlenen kâğıtlar,

13/7/1956 tarihli ve 6802 sayılı Gider Vergisi Kanunu ile ihdas edilen Banka ve Sigorta Muameleleri Vergisinden, 1/7/1964 tarihli ve 488 sayılı Damga Vergisi Kanunu ile ihdas edilen Damga Vergisinden, 2/7/1964 tarihli ve 492 sayılı Harçlar Kanunu gereğince alınan harçlar ve diğer kanunlarda yer alan vergi, resim ve harçlar ile 12/9/1960 tarihli ve 80 sayılı Kanuna göre alınan hal rüsumundan müstesnadır (ihracat: 2008/6 numaralı Tebliğ, 4).

Bu sebeple faktoring şirketlerinin ihracat ve döviz kazandırıcı hizmet ve faaliyetleri ile ilgili yaptıkları bütün hizmetler BSMV, Damga vergisi ve Harçlardan istisna edilmiştir.

\subsubsection{Banka Sigorta Muamele Vergisi (BSMV)}

Banka ve Sigorta şirketlerinin 3226 sayılı Finansal Kiralama Kanunu'na göre yaptıkları işlemler haricinde tüm işlemleri kapsamında nakden veya hesaben aldıkları tüm paralar BSMV'ye konu olmaktadır. Buna ilaveten Gider Vergileri kanununda da yer alan 90 sayılı Kanun Hükmünde Kararname uyarınca" ikraz işleriyle uğraşanlar banker kapsamında BSMV mükellefidir." Buna ilaveten "90 sayılı Kanun Hükmünde Kararnamenin 2 nci maddesi kapsamında düzenlenen ödünç para verme işleriyle uğraşan gerçek kişiler ile faktoring ve finansman şirketleri banker kapsamında BSMV mükellefi olup, bunların yaptığı 6802 sayılı Kanunun 28 inci maddesinin ikinci fıkrasında belirtilen işlemler BSMV ye tabidir. Dolayısıyla bu işlemlerin dışında kalan diğer işlemleri ise KDV ye tabi olacaktır." (87 seri numaralı Gider Vergileri Tebliği,1).ilgili kanunlar da vurgulandığı üzere iç piyasadan doğan alacakların faktoring işlemine konu olması sonucu oluşan ücret ve komisyon BSMV'ye tabidir.

Ihracat Factoring işlemlerinde ise faktoring şirketlerinin ihracat ve döviz kazandırıcı hizmet ve faaliyetleri kapsamına girdiğinden dolayı faktoring ücret ve komisyonları BSMV'den muaftır.

\section{FAKTORING ŞiRKETLERININ ELDE ETTIĞi GELIR GETIRICi UNSURLARININ 18 NOLU TÜRKIYE MUHASEBE STANDARDI ÇERÇEVESINDE (TMS 18) MUHASEBELEŞTíRILMESi 4.3 TMS 18 "Hasılat" Standardının Muhasebe Kayıtlarına Etkisi}

18 Nolu Türkiye Muhasebe Standardı (TMS 18) işletmelerin bir muhasebe döneminde elde ettiği hasılatın ne şekilde muhasebeleştirileceği, muhasebeleşen hasılatın gelirlere nasıl alınacağını ve nasıl ölçüleceğini açıklamaktadır.

Standartta ki tanımıyla hasılat "Ortakların sermayeye katkıları dışında özkaynakta artışla sonuçlanan ve işletmenin dönem içindeki olağan faaliyetlerinden elde edilen brüt ekonomik tutardır." (TMS 18, 7). Mal satışları, hizmet sunumları ve işletme varlıklarının başkaları tarafından kullanılmasından sağlanan faiz, isim hakları ve temettülerden kaynaklanan gelirlerin muhasebeleştirilmesinde ilgili standart uygulanmaktadır.

Söz konusu standartta finansal kiralama sözleşmeleri, özkaynak yöntemi kullanılarak muhasebeleştirilen yatırımlardan sağlanan temettüler, sigorta poliçeleri, finansal varlık veya finansal yükümlülüklerin gerçeğe uygun değerindeki değişmeler veya bunların elden çıkarılması, diğer dönen varlıkların değerindeki değişmeler, tarımsal faaliyetlere ilişkin canlı varlıkların ilk defa muhasebeleştirilmesi veya gerçeğe uygun değerindeki değişmeler, tarımsal ürünlerin ilk defa kayda alınması ve madencilik faaliyetlerinden elde edilen hasılat kapsam dışı bırakılmıştır.

Hasılat kavramı işletmenin özkaynaklarında artışa sebep olur, olağan faaliyetlerden elde edilir, sürekliliği vardır ve kazanç kavramından farklı olarak brüt olarak ölçülür. Buna karşılık mal ve hizmet, satış, KDV vergisi veya iş yaptıkları firma adına alınan tutarlar hasılat kavramı içine girmez.

TMS 18'e göre hasılat alınan veya alınacak olan bedelin gerçeğe uygun değeri ile ölçülür. Gerçeğe uygun değer; karşılıklı pazarlık ortamında, bilgili ve istekli gruplar arasında bir varlığın el değiştirmesi yada bir borcun ödenmesi durumunda ortaya çıkan tutardır.

Hasılat standardındaki en önemli husus şüphesiz vade ayrımıdır. İşlemin vadeli veya vadesiz olması durumunda vadeli satışlardaki gelirin içerisinde yer alan faiz gelirinin ayrıştırılıp gerçek satış bedelinin bulunması gerekmektedir. Örneğin, kredili satışlarda ayrıştırılan vade farklarından kaynaklanan faiz tutarı, dönemin faiz 
gelirlerine ilave edilir ve böylece işletme satışlarını ve brüt satış karını gerçeğe uygun şekilde yansıtmakta ve net satış karınında optimum seviyede doğru hesaplanmasına fırsat sağlar.

Vadeli yapılan satış tutarının tamamı satış hasılatı olarak muhasebeleştirilmekte, ancak yıl sonu geldiğinde, senetli olan alacaklar için reeskont işlemi yapılarak dolaylı bir şekilde düzeltilmektedir. Ancak, yapılan bu uygulama sadece senetli alacaklar için söz konusudur, senetsiz olan alacaklar için böyle bir düzeltme yapılmamaktadır (Özerhan, 2015). Özerhan (2015)'te vurgulandığı üzere standarda uyulduğunda yılsonunda reeskont işlemi yapılmasına gerek kalmamaktadır.

Standarda göre mal satışında satış bedeli gerçeğe uygun değeri ile muhasebeleşmelidir. Bir başka deyişle satışın tamamı hasılat yazılmalıdır. Buna karşııık vadeli satışlarda gelirin içerisinde yer alan faiz gelirinin ayrıştırılıp vade farkı faiz geliri olarak kaydedilmelidir. Bu durumda vadeye kadar iskonto edilmiş tutar gerçeğe uygun değeri oluşturmaktadır. İlgili faiz gelirinin Vade farkı faiz hasılatı hesabı ile kalanının satış hasılatı hesabına aktarılarak muhasebeleşmesi gerekmektedir.

Standarda göre mal satışında hasılatın gelir olarak kaydedilmesi için malın mülkiyet hakkı ile söz konusu mülkiyete ilişkin risk ve getirilerinde alıcıya devrolması gerekir. Bu noktada önemli olan husus bu şart sağlanmaz ise işlem satış olarak kabul edilemez ve bu sebeple gelir tahakkuku da yapılamaz. Yapılan izahatlar ışığında işlemle ilgili maliyetler ve hasılatlar güvenilir bir şekilde ölçülebilmeli ve maliyetin ölçülemediği durumlarda ilgili tutar belirlenene kadar gelir kaydı oluşturulmamalıdır.

Hizmet satışında ise raporlama dönemi sona erdiğinde işlemin tamamlanma düzeyinin güvenilir bir biçimde ölçülebilmesi gerekmektedir. Hizmet maliyetle eşleştirilip tamamlandıkça tamamlanma yüzdesine göre gelir kaydedilmelidir. Bazı durumlarda söz konusu tamamlama düzeyi etkin ve doğru bir biçimde ölçülemeyebilir. Bu gibi durumlarda mali tablolara giderlerin geri kazanılanilir tutarı yansıtılabilinmesine rağmen işlem güvenilir bir biçimde sonuçlanamadığından mali tablolara kar yansıtılmaktan kaçınılır.

Daha önce finansal tablolara yansıtılmış olan hasılat tutarının tahsil edilebilirliği konusunda bir belirsizlik ortaya çıktığında, tahsil edilemeyen veya tahsil edilebilmesi muhtemel olmaktan çıkan tutar başlangıçta hasılat olarak muhasebeleştirilmiş tutarın düzeltilmesi yerine, gider olarak finansal tablolara yansıtılır (Akbulut, 2015). Akbulut (2015)'te belirtildiği üzere hasılat sadece ekonomik yararın işletme tarafından elde edilmesi muhtemel olduğunda finansal tablolarda yer almalıdır.

Faiz, isim hakkı ve temettülerin ölçülmesindeki usul aşağıdaki gibidir;

Faiz, "TMS 39 Finansal Araçlar: Muhasebeleştirme ve Ölçme" Standardında belirlenen etkin faiz yöntemine göre muhasebeleştirilir,

İsim hakları; ilgili sözleşmenin özü dikkate alınarak, tahakkuk esasına göre muhasebeleştirilir,

Temettüler; hissedarların tahsil etme hakları ortaya çıktığında finansal tablolara yansıtılır (TMS 18, 30).

Standart hasılat oluşturma niteliği olan her bir işlemin ayrı ayrı ölçülebildiği durumlarda her birinin ayrı bir hasılat kalemi olarak muhasebeleştirilmesini ve mali tablolara aktarılmasını ilke olarak benimsemiştir (Aygün,2012). Aygün (2012)'de vurgulandığı üzere birbiriyle bağlantılı olan işlemler birlikte değerlendirilebilinir. Örneğin; bilgisayar ticareti ve servis hizmeti veren bir firma, son teknolojiye sahip masaüstü bilgisayarı üç bin TL'na satmaktadır. Fakat müşteri yüz elli TL daha fazla verdiğinde bir yıl boyunca bilgisayarın kullanıcıdan kaynaklı hataların çözümü ve tamiratı işini ücretsiz yapacaktır. TMS 18 "Hasılat" standardı açısından buradaki hasılat tutarı üç bin TL'dır. Tamirat için alınan yüz elli TL ise tamirat işleminin yapıldığı dönemde mali tablolara hasılat olarak entegre edilmelidir.

\subsection{TMS 18 “HASILAT” STANDARDI ILE TEK DÜZEN MUHASEBE SISTEMININ ÖRNEK ÜZERINDE KARŞILAŞTIRILMASI}

Ece Paz. Tic. A.Ş. Aralık 2015 tarihinde faaliyete başlamıştır. Söz konusu firma fason olarak ürettirdiği doğal meyve kurusunu uluslararası düzeyde satmaktadır. Ürettirilen meyve kuruları fason firmalar tarafından doğal makro klima özelliği bulunan bölgelerde açık havada kurutulmaktadır. Dolayısıyla kurutma süresi 1 ay sürmektedir. İşletme Ocak 2016 tarihinden itibaren 2 ay boyunca yeni ürün almadan elindeki stokları eritmek istemektedir. Bu sebeple pazarda arayış yapmakta olup elindeki stokları 3 ay vadeli senet karşılığında satmayı 
amaçlamaktadır. 1 tonluk üretimin maliyeti 10.000 TL olan meyve kurularının peşin alındığı takdirde $14.000 \mathrm{TL}$ 'na satmaktadır. 3 ay vadeli fiyatı ise 20.000 TL'dır.

Üç ayda bir finansal tablo düzenleyen ve devamlı envanter yöntemi kullanan Ece Paz. Tic. A.Ş.'nin 1 Ocak 2016 tarihli dönem başı bilançosu ve Mart 2016 dönemine kadar olan işlemleri aşağıdaki gibidir; (KDV Dahil değildir)

\begin{tabular}{|c|c|c|c|}
\hline \multicolumn{4}{|c|}{ Ece Paz. Tic. A.S. 'nin 01.01.2016 tarihli bilançosu } \\
\hline I.Dönen Varlıklar & $210.500,00 \mathrm{TL}$ & III. Kısa Vadeli Yabancı Kaynaklar & $100.000,00 \mathrm{TL}$ \\
\hline Kasa & $30.000,00 \mathrm{TL}$ & Saticilar & $70.000,00 \mathrm{TL}$ \\
\hline Banka & $50.000,00 \mathrm{TL}$ & Borç Senetleri & $30.000,00 \mathrm{TL}$ \\
\hline Alacak Senetleri & $30.500,00 \mathrm{TL}$ & IV. Uzun Vadeli Yabancı Kaynaklar & $0,00 \mathrm{TL}$ \\
\hline Ticari Mallar & $100.000,00 \mathrm{TL}$ & V. Özkaynaklar & $210.000,00 \mathrm{TL}$ \\
\hline II.Duran Varlıklar & 99.500,00 TL & Sermaye & $200.000,00 \mathrm{TL}$ \\
\hline Demirbaşlar & $25.000,00 \mathrm{TL}$ & Dönem Net Karı & $10.000,00 \mathrm{TL}$ \\
\hline Bina & $75.000,00 \mathrm{TL}$ & & \\
\hline Birikmiş Amortisman & $-500,00 \mathrm{TL}$ & & \\
\hline Aktif Varlıklar Toplamı & $\underline{310.000,00 \mathrm{TL}}$ & Pasif Varlıklar Toplamı & $\underline{310.000,00 \mathrm{TL}}$ \\
\hline
\end{tabular}

İşletmenin 01.01.2016 tarihi itibarı ile hasılat standardını kullanarak muhasebe kayıtlarını aşağıdaki şekilde oluşturmuştur.

Ocak ayında 2 tonluk vadeli satış yapıldığı takdirde,

\section{Alacak Senetleri}

380 Gel. Ayl. Ait. Gelirler

40.000,00 TL

Şubat ayında 3 tonluk satış yapıldığında,

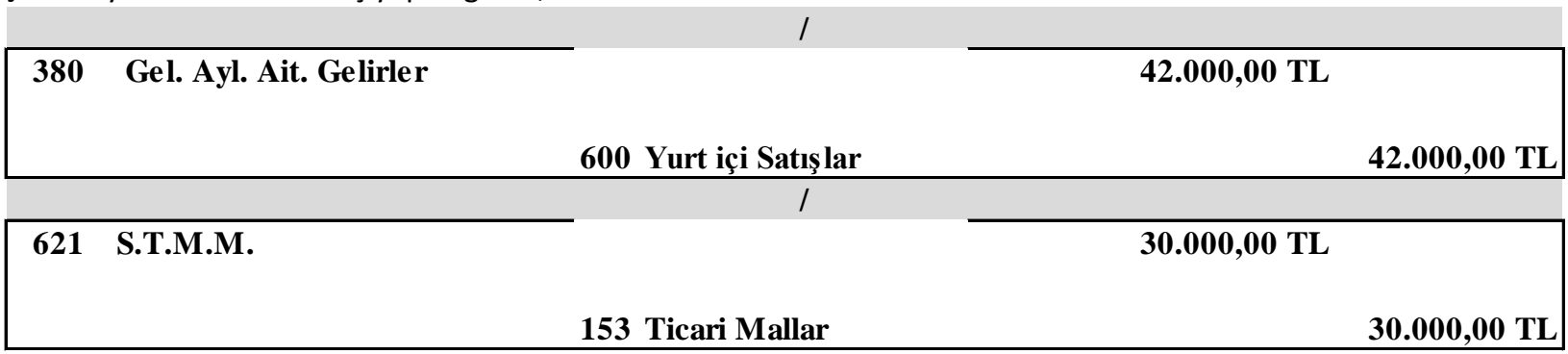

Şubat ayında ayrıca 1 tonluk vadeli satış yapıldığında,

121 Alacak Senetleri

$20.000,00$ TL

380 Gel. Ayl. Ait. Gelirler

$20.000,00$ TL

Ocak ayında yapılan 2 tonluk satışın vade farklarının hasılat olarak kaydedilmesi,

380 Gel. Ayl. Ait. Gelirler

$1.000,00$ TL

642 Faiz Gelirleri

$1.000,00$ TL

Mart Ayında 1 tonluk satış yapıldığında, 


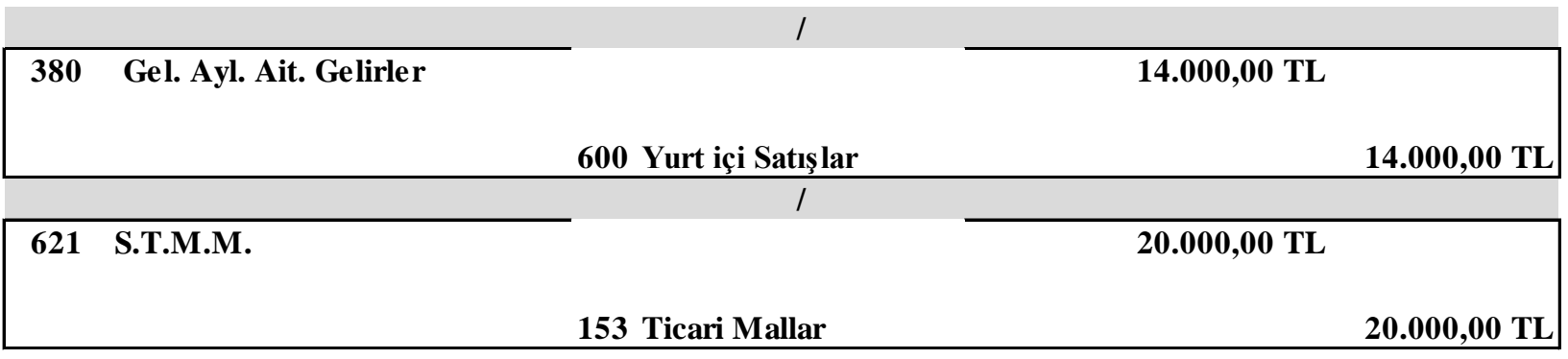

Ocak ayında yapılan 2 tonluk satışın vade farklarının hasılat olarak kaydedilmesi,

\begin{tabular}{|lrrr|}
\hline 380 & Gel. Ayl. Ait. Gelirler & $/$ & \\
\cline { 3 - 4 } & & $1.000,00$ TL \\
& & 642 Faiz Gelirleri & $1.000,00$ TL \\
\hline
\end{tabular}

Şubat ayında yapılan 1 tonluk satışın vade farklarının hasılat olarak kaydedilmesi

$$
380 \text { Gel. Ayl. Ait. Gelirler }
$$

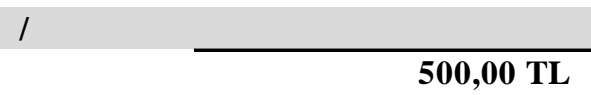

642 Faiz Gelirleri

Ece Paz. Tic. A.Ş.'nin 31 Mart 2016 sonu itibarıyla Gelir Tablosu ve Bilançosu aşağıdaki gibidir;

\section{Ece Paz. Tic. A.S. Gelir Tablosu (31.03.2016)}

\begin{tabular}{|l|r|}
\hline Brüit Satışlar & $\mathbf{5 6 . 0 0 0 , 0 0 ~ T L}$ \\
\hline Satış İndirimleri (-) & $0,00 \mathrm{TL}$ \\
\hline Net Satışlar & $56.000,00 \mathrm{TL}$ \\
\hline Satışların Maliyeti (-) & $50.000,00 \mathrm{TL}$ \\
\hline Brüt Satış Karı & $\mathbf{6 . 0 0 0 , 0 0 ~ T L}$ \\
\hline Faiz Gelirleri & $2.500,00 \mathrm{TL}$ \\
\hline Dönem Net Karı & $\mathbf{8 . 5 0 0 , 0 0 ~ T L}$ \\
\hline
\end{tabular}

\begin{tabular}{|c|c|c|c|}
\hline \multicolumn{4}{|c|}{ Ece Paz. Tic. A.S. 'nin 01.01.2016 tarihli bilancosu } \\
\hline I.Dönen Varlıklar & $220.500,00 \mathrm{TL}$ & III. Kısa Vadeli Yabancı Kaynaklar & $101.500,00 \mathrm{TL}$ \\
\hline Kasa & $30.000,00 \mathrm{TL}$ & Saticilar & 70.000,00 TL \\
\hline Banka & $50.000,00 \mathrm{TL}$ & Borç Senetleri & $30.000,00 \mathrm{TL}$ \\
\hline Alacak Senetleri & $90.500,00 \mathrm{TL}$ & Gel. Ayl. Ait Gelirler & $1.500,00 \mathrm{TL}$ \\
\hline Ticari Mallar & $50.000,00 \mathrm{TL}$ & IV. Uzun Vadeli Yabancı Kaynaklar & $\mathbf{0 , 0 0}$ TL \\
\hline II.Duran Varlıklar & $99.500,00 \mathrm{TL}$ & V. Özkaynaklar & $218.500,00 \mathrm{TL}$ \\
\hline Demirbaşlar & $25.000,00 \mathrm{TL}$ & Sermaye & $200.000,00 \mathrm{TL}$ \\
\hline Bina & $75.000,00 \mathrm{TL}$ & Geçmiş Yıllar Karı & $10.000,00 \mathrm{TL}$ \\
\hline Birikmiş Amortisman & $-500,00 \mathrm{TL}$ & Dönem Net Karı & $8.500,00 \mathrm{TL}$ \\
\hline Aktif Varlıklar Toplamı & $\underline{320.000,00 \mathrm{TL}}$ & Pasif Varlıklar Toplamı & $\underline{320.000,00 \mathrm{TL}}$ \\
\hline
\end{tabular}

İşletmenin 01.01.2016 tarihi itibarı ile tek düzen muhasebe sistemini kullanarak muhasebe kayıtlarını aşağıdaki gibi oluşturmuştur. Faturalar vadeli bedel üzerinden düzenlenmekte ve vade farkı gösterilmemektedir. İlgili muhasebe kayıları aşağıdaki gibidir;

Ocak ayında 2 tonluk vadeli satış yapıldığı takdirde, 


\begin{tabular}{|c|c|c|}
\hline & l & \\
\hline \multirow[t]{2}{*}{121 Alacak Senetleri } & & 40.000,00 TL \\
\hline & 600 Yurtiçi Satışlar & $40.000,00 \mathrm{TL}$ \\
\hline & 1 & \\
\hline \multirow[t]{2}{*}{621 S.T.M.M. } & & $20.000,00$ TL \\
\hline & 153 Ticari Mallar & $20.000,00 \mathrm{TL}$ \\
\hline
\end{tabular}

Şubat ayında 1 tonluk vadeli satış yapııdığında,

$$
\text { I }
$$

121 Alacak Senetleri

20.000,00 TL

600 Yurtiçi Satış lar

$20.000,00$ TL

621 S.T.M.M.

/

$10.000,00 \mathrm{TL}$

153 Ticari Mallar

$10.000,00 \mathrm{TL}$

Ece Paz. Tic. A.Ş.'nin 31 Mart 2016 sonu itibarıla Gelir Tablosu ve Bilançosu aşağıdaki gibidir;

Ece Paz. Tic. A.S. Gelir Tablosu (31.03.2016)

\begin{tabular}{|l|r|}
\hline Brüt Satışlar & $\mathbf{6 0 . 0 0 0 , 0 0 ~ T L}$ \\
\hline Satış İndirimleri (-) & $0,00 \mathrm{TL}$ \\
\hline Net Satışlar & $60.000,00 \mathrm{TL}$ \\
\hline Satışların Maliyeti (-) & $30.000,00 \mathrm{TL}$ \\
\hline Brüt Satış Karı & $\mathbf{3 0 . 0 0 0 , 0 0}$ TL \\
\hline Dönem Net Karı & $\mathbf{3 0 . 0 0 0 , 0 0}$ TL \\
\hline
\end{tabular}

\begin{tabular}{|c|c|c|c|}
\hline \multicolumn{4}{|c|}{ Ece Paz. Tic. A.S. 'nin 01.01.2016 tarihli bilancosu } \\
\hline I.Dönen Varlıklar & $240.500,00 \mathrm{TL}$ & III. Kısa Vadeli Yabancı Kaynaklar & $100.000,00 \mathrm{TL}$ \\
\hline Kasa & $30.000,00 \mathrm{TL}$ & Saticilar & 70.000,00 TL \\
\hline Banka & $50.000,00 \mathrm{TL}$ & Borç Senetleri & $30.000,00 \mathrm{TL}$ \\
\hline Alacak Senetleri & $90.500,00 \mathrm{TL}$ & IV. Uzun Vadeli Yabancı Kaynaklar & $\mathbf{0 , 0 0} \mathrm{TL}$ \\
\hline Ticari Mallar & $70.000,00 \mathrm{TL}$ & V. Özkaynaklar & $240.000,00 \mathrm{TL}$ \\
\hline II.Duran Varlıklar & $99.500,00 \mathrm{TL}$ & Sermaye & $200.000,00 \mathrm{TL}$ \\
\hline Demirbaşlar & $25.000,00 \mathrm{TL}$ & Geçmiş Yıllar Karı & $10.000,00 \mathrm{TL}$ \\
\hline Bina & $75.000,00 \mathrm{TL}$ & Dönem Net Karı & $30.000,00 \mathrm{TL}$ \\
\hline Birikmiş Amortisman & $-500,00 \mathrm{TL}$ & & \\
\hline Aktif Varlıklar Toplamı & $340.000,00 \mathrm{TL}$ & Pasif Varlıklar Toplamı & $\underline{340.000,00 \mathrm{TL}}$ \\
\hline
\end{tabular}

\subsection{TMS 18 "Hasılat" Standardının Faktoring İşlemleri Açısından Değerlendirilmesi}

Faktoring işletmelerinin kayıtları, 24.12.2013 tarih ve 28861 sayılı Resmi Gazete'de yayımlanan “Finansal Kiralama, Faktoring ve Finansman Şirketlerince Uygulanacak Tekdüzen Hesap Planı ve İzahnamesi ile Kamuya Açıklanacak Finansal Tabloların Biçim ve İçeriği Hakkında Tebliğ"de yer alan hesap planına göre yapılmaktadır.

İlgili tebliğ de belirtildiği üzere;

Iskontolu faktoring alacakları 100, 101 Kısa Vadeli iskontolu Faktoring Alacakları - T.P., Y.P. ile 102, 103 Orta ve Uzun Vadeli Iskontolu Faktoring Alacakları - T.P., Y.P. hesaplarında izlenir. Hesabın bakiyesi iskonto edilen Türk 
parası ve yabancı para faktoring alacaklarından henüz vadesi gelmemiş ve tahsil edilmemiş olanların tutarını gösterir.

100, 101 Kısa Vadeli iskontolu Faktoring Alacakları - T.P., Y.P. ve 102, 103 Orta ve Uzun Vadeli iskontolu Faktoring Alacakları - T.P., Y.P. hesaplarında izlenen tutarlar ile müşteriye yapılan ödeme arasındaki fark 104, 105 iskontolu Faktoring Alacaklarından Kazanılmamış Gelirler - T.P.,Y.P. hesaplarının alacağında izlenir. Dönem sonlarında dönemi ilgilendiren gelirler 104, 105 iskontolu Faktoring Alacaklarından Kazanılmamış Gelirler T.P.,Y.P. hesaplarının borcuna ilgili faiz geliri hesabının alacağına kaydedilerek dönem gelirlerine yansıtılır.

iskontolu faktoring alacakları dışında kalan diğer faktoring alacakları ilgili hesaplarda izlenir.

Faktoring işlemlerinin bilanço içi veya bilanço dışı hesaplarda izlenmesi ve bilanço dışı hesaplarda izlenen faktoring işlemlerinin hangi aşamada bilanço içi hesaplarda izleneceği hususlarında, ilgili Türkiye Muhasebe Standartlarında belirtilen tahakkuk esası ile muhasebeleştirme ve bilanço dışı bırakmaya ilişkin esaslar dikkate alınır. (Finansal Kiralama, Faktoring ve Finansman Şirketlerince Uygulanacak Tekdüzen Hesap Planı ve İahnamesi ile Kamuya Açıklanacak Finansal Tabloların Biçim ve İçeriği Hakkında Tebliğ, 10).

Buna ilaveten “392020 Peşin Tahsil Edilen Faiz, Ücret ve Komisyonlar” hesabının mahiyetine baktığımızda bu hesaba kullandırılan krediler için komisyon ve benzer türdeki masrafların peşin olarak tahsil edilmesi ve tahsilat anında 392020 hesabına kayıt atılır. TMS hükümleri çerçevesinde etkin faiz oranı dönemsellik ilkesine bağlı olarak ilgili dönemin gelir hesabının alacağına yazıır ve dönem gelirine yansıtılır. Ayrıca Faktoring işlemlerinden kaynaklı alacaklar için alınan faizler alacağın çeşidine göre ilgili hesaplara aktarılır.

Faktoring işlemlerinde hasılat genellikle vadeye yayılmıştır, finans kurumlarında ise kar/zarar durumlarını ihtiyatlılık gereği günlük olarak tutmak durumundadır. Faktoring işleminde peşin iskonto yöntemi ve spot işlem yöntemi ağırlık kazanan işlem yöntemleridir.

Peşin iskonto yönteminde hasılat baştan hesaplanır ve müşteriye fatura edilir, hasılat hesap planında "104İskontolu Faktoring Alacaklarından Kazanılmamış Gelirler" hesabına kaydedilir ve bu hesaptan günlük olarak gelir hesaplarına aktarım yapılır. Burda önemli olan husus faiz geliri ise 500 grubuna, komisyon geliri ise 700 grubundaki hesaplara aktarım yapılmalıdır. Spot işlemlerde ise hasılat ancak karşılıklı belirlenen vadede (aysonu, işlem bitimi vb. durumlar) tahakkuk eder ve vadeye kadar geçen süre için yine günlük reeskont hesaplaması yapılarak gelir hesaplarına aktarım yapılır. Bu işlemlerdeki amaç, hasılatın elde edildiği zaman peşin olarak gelir yazılması yada işlem bitimini bekleyip en sonunda gelir yazmak değil, işlemin başlangıç ve vadesine kadar geçen süre içine yayılararak gelir hesaplarına kaydedilmesidir.

Faktoring işlemlerinde vade önemli bir unsurdur ve hasılat vadeye yayılarak işlem görür. Peşin iskonto yönteminde hasılat en başta hesaplanır ve "104 İskontolu Faktoring Alacaklarından Kazanılmamış Gelirler" hesabında muhasebeleşir. Vade bitimine kadar faiz ve komisyon için günlük olarak gelir hesaplarına kayıt yapılır. Örnek muhasebe kaydı aşağıdaki gibidir;

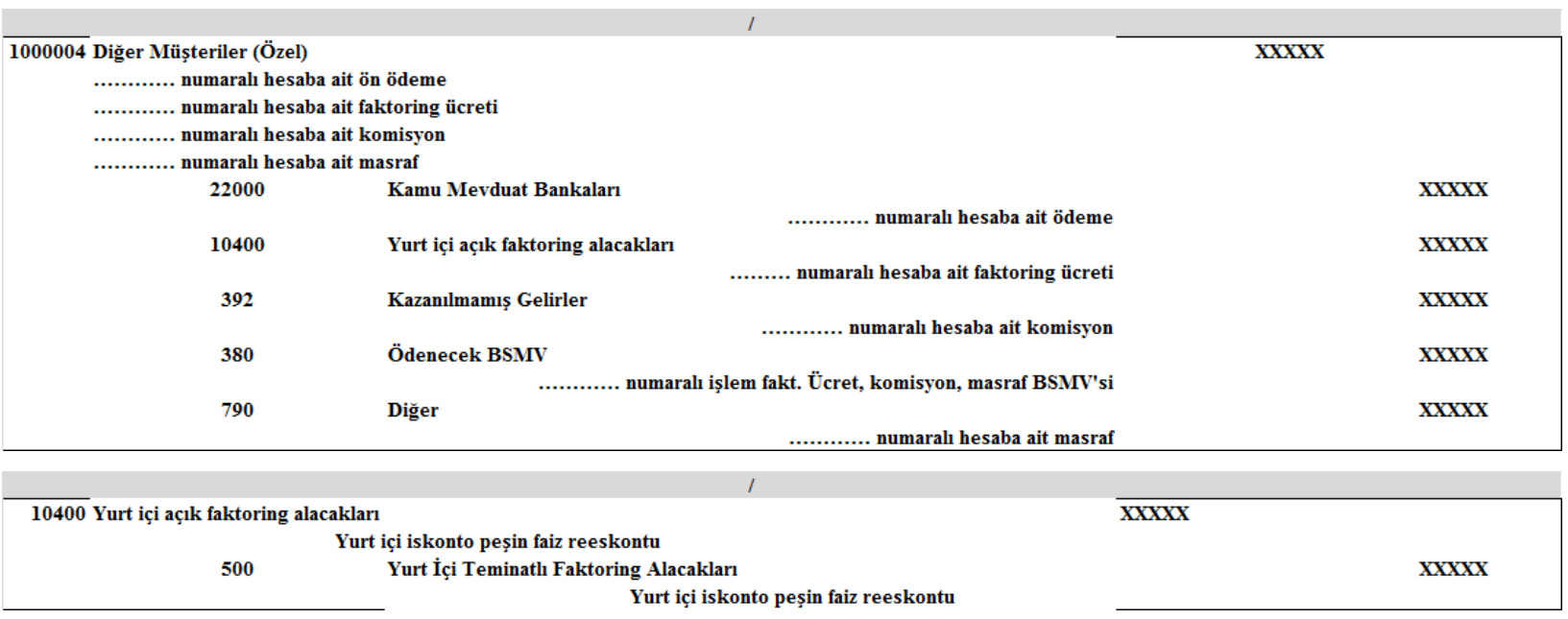

Spot işlem yönteminde kullandırım yapılır ve vade bitimine kadar hasılat günlük reeskont hesaplaması ile gelir hesaplarına kaydedilir. Örnek muhasebe kaydı aşağıdaki gibidir; 


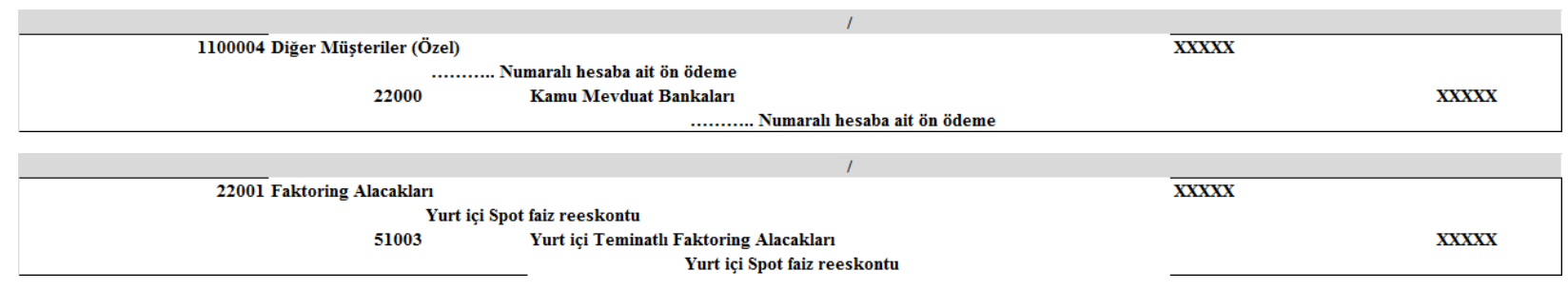

Yapılan izahatlar ışığında, TMS 18 "Hasılat" uygulaması faktoring işlemlerinin muhasebeleştirilmesinde uzun yıllardır ilgili otorite ile süre gelen fikir ayrılıklarını ortadan kaldırmış olup sektörün çok faydalandığı bir standarttır.

Hasılat standardı işletmelerin uygulaması gereken 'temel' standartlardan birisidir. Hasılat standardı uyarınca gerçekleştirilecek muhasebe kayıtlarına bağlı olarak oluşturulacak finansal tablolar gerçeğe uygun finansal analizlerin yapılmasına olanak sağlayacak ve bu durum mevcut ve potansiyel yatırımcıların karar alma süreçlerine olumlu katkı sağlayacaktır (Polat vd.,2014). Polat vd. (2014)'nin vurguladığı üzere hasılatın doğru tespit edilmesi gerekmesi hususundan hareketle faktoring işlemlerinde, faktoring şirketleri kendilerine temlik edilen alacaklarla ilgili;

A. Peşin iskonto yönteminde faktoring ücretini ve komisyonunu hesaplayıp fatura tutarından bu rakamı düşerek firmaya ön ödeme yapar.

B. Faktoring ücretini adat (Faize esas olan anapara ile paranın kullanıldığı gün sayısının çarpımı) üzerinden çalıştırarak fatura borçlusundan tahsilat yapıldığında ve/veya müşteri ile anlaşılan vadede birikmiş factoring ücreti ve komisyonunu (işlemin vadesini esas alarak) tahsil eder.

Faktoring işletmelerinde adatlı faiz hesaplama ve/veya peşin iskonto ile faiz hesaplama şeklinde iki yöntemi de kullanılabilinir. TMS 18 standardı öncesi a seçeneğinde belirtilen işlemin muhasebeleştirilmesinde karmaşa söz konusu idi. Alacağı temlik eden şirketler peşin iskonto ile factoring ücreti ve komisyonunu tek kalemde iskonto işleminin yapıldığı gün tamamını gider yazmak suretiyle muhasebeleştirebiliyordu. Buna da kanunen bir engel bulunmamaktaydı. Bu sebeple ilgili otorite gelir ve giderin aynı dönemde muhasebeleşmesi mantığından hareketle faktoring şirketlerinin elde ettiği gelir getirici unsurlarını tek kalem olarak işlemin yapıldığı tarihte gelir olarak yazmasını doğru buluyordu.

TMS 18 "Hasılat" standardının gelmesi ile peşin iskonto ile faktoring işlemi yapan faktoring işletmesi de alacağını temlik eden firmada bu faktoring ücret ve komisyonunu faydalanma dönemlerine ayrıştırarak muhasebeleştirmektedir. İç piyasa işlemlerinde genelde peşin iskonto yöntemi kullanılırken ihracat fonlamalarında ise adat üzerinden işleyen faiz (faktoring ücreti) hesaplama yöntemi tercih edilir. Bu yöntemde dönemsel muhasebeleştirme söz konusudur.

Faiz gelirini hesaplarken TMS 39 “Finansal Araçlar: Muhasebeleştirme ve Ölçme” standardında yer alan etkin faiz yöntemi baz alınır. Söz konusu yöntemde faiz hasılatının ve faiz giderinin dağıtımından belirlenir. Finansal varlık veya borcun itfa edilmiş maliyetlerinin hesaplanarak ilişkili olduğu döneme faiz geliri veya gideri olarak dağıtılmasıdır. Bir başka deyişle gelecekteki nakit ödemeleri (tahsilatları) tam olarak net defter değerine indirgeyen orandır.

\subsection{TMS 18 "Hasılat" Standardı İle Örnek Faktoring Muhasebe Kayıtlarının İncelenmesi}

TMS 18 "Hasılat" standardı ile gelirin faydalanma dönemlerine ayrıştırılarak muhasebeleştirilmesini rücu edilemez faktoring yöntemi ile incelersek;

Bilgin Koltuk Üretim Anonim Şirketi 01.01.2015 tarihinde ABC A.Ş.'ye koltuklarını 45 gün vadeli olarak \%18 KDV dahil 120.000 TL'ye satımıştır. Bilgin Koltuk Üretim A.Ş., ABC A.Ş.'den olan 45 gün vadeli senetsiz alacakları için BAŞ Faktoring A.Ş.'ye başvurarak rücu edilemez faktoring sözleşmesini imzalamıştır (iskontolu). BAŞ Faktoring A.Ş. aralarında yaptıkları sözleşme gereğince alacakları devralarak \%70 oranında ön ödeme taahhüdünde bulunmuştur. BAŞ Faktoring A.Ş. \% 3 oranında hizmet komisyonu ve \% 4 oranında garanti komisyonu talep etmiştir. Piyasa faiz oranını ise \%18 olarak belirlemiştir. \% 5 oranındaki BSMV ise 15.03.2015 te ödenecektir. Sözleşme uyarınca damga vergisi yükümlülüğü BAŞ Faktoring A.Ş.'ye aittir. Vade bitiminde BAŞ Faktoring A.Ş. tüm alacakları tahsil etmiştir.

Yapılan izahatlar ışığında BAŞ Faktoring A.Ş.'nin yapacağı muhasebe kayıtları ve hesaplamaları aşağıdaki gibidir, 


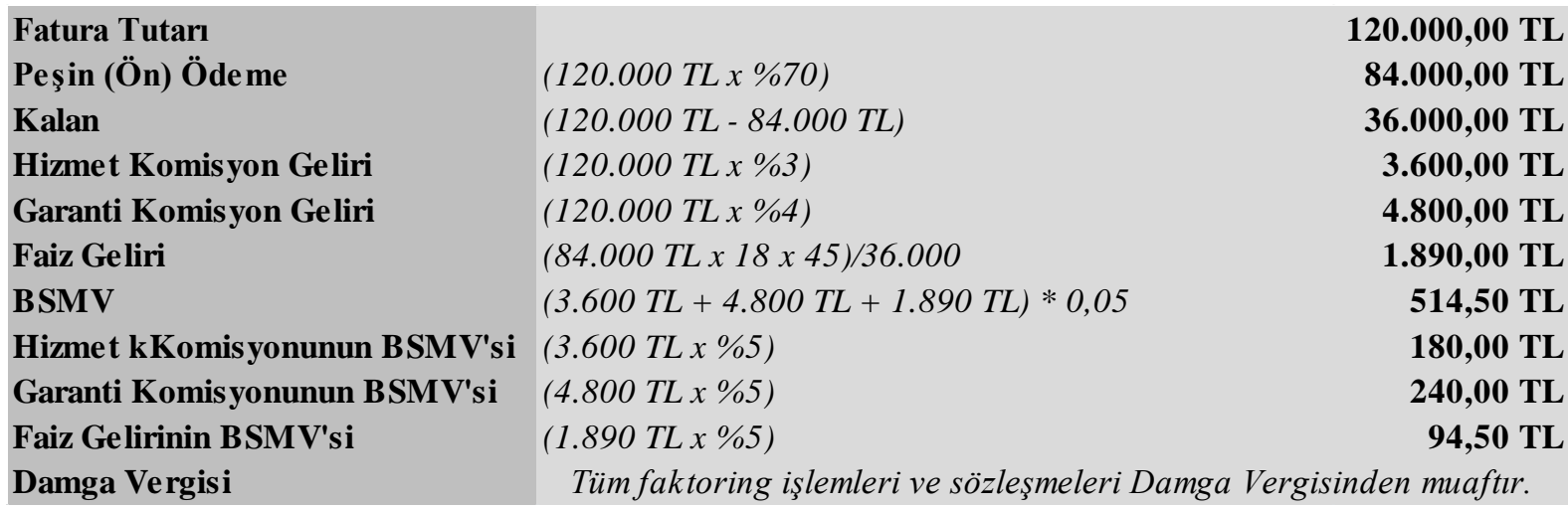

Faktoring sözleşmesi imzalandığında,

\begin{tabular}{|c|c|c|c|}
\hline & \multicolumn{3}{|c|}{01.01 .2015} \\
\hline \multirow{2}{*}{$\begin{array}{l}100 \\
100.00\end{array}$} & Kısa Vadeli İskontolu Faktoring & Alacakları Hs. & $120.000,00 \mathrm{TL}$ \\
\hline & Yurtiçi Faktoring Alacakları & & \\
\hline 100.00 .1 & Rücu Edilemez & & \\
\hline & 356 & Faktoring İșlemlerinden Borçlar Hs. & $120.000,00 \mathrm{TL}$ \\
\hline & 356.01 & Rücu Edilemez & \\
\hline
\end{tabular}

Riskin üstlenilmesi,

$$
\text { 01.01.2015 }
$$

950 Riski üstlenilen Faktoring İşle mlerinden Alacaklar Hs.

$120.000,00 \mathrm{TL}$ 952 Riski üs tlenilen Faktoring İşle mlerinden Borçlar Hs.

Müşteri firma olan Bilgin Koltuk Üretim Anonim Şirketi’ne ön ödeme yapılması,

\begin{tabular}{|c|c|c|}
\hline & \multicolumn{2}{|c|}{ 01.01.2015 } \\
\hline 356 & Faktoring İșle mle rinden borçlar hs. & $84.000,00$ TL \\
\hline 356.01 & Rücu Edilemez & \\
\hline & 010 Kasa Hs. & $84.000,00$ TL \\
\hline
\end{tabular}

Komisyon ve faiz geliri ile BSMV'nin ilgili hesaplara aktarılması,

\begin{tabular}{|c|c|c|c|}
\hline \multicolumn{4}{|c|}{ 16.01.2015 } \\
\hline \multicolumn{4}{|c|}{ Kısa Vadeli İskontolu Faktoring Alacaklan Hs. } \\
\hline 100.00 & \multicolumn{3}{|c|}{ Yurtiçi Faktoring Alacakları } \\
\hline \multicolumn{4}{|c|}{ Rücu Edilemez } \\
\hline & 700 & \multirow{2}{*}{ İskontolu Faktoring Alacaklarından alınan ücret ve komisyonlar hs. } & \multirow{2}{*}{$\begin{array}{l}8.400,00 \mathrm{TL} \\
1.890,00 \mathrm{TL}\end{array}$} \\
\hline & 500 & & \\
\hline & 380 & Ödenecek Vergi, Resim, Harç, Prim ve Fonlar Hs. & \multirow[t]{2}{*}{$514,50 \mathrm{TL}$} \\
\hline & & 380.10.2 BSMV & \\
\hline
\end{tabular}

TMS 18 "Hasılat" standardı olmasaydı gelecek aylarda elde edilecek gelir getirici unsurlar direkt hasılat hesabına yazılacaktı böylece hasılat hesabının ortalama vadeye göre işlenmesi gerekecekti. İlgili örnekte bahsedildiği gibi vade 45 gün iken 1 Şubat tarihinde 30 günlük faiz işlememiz gerekecekti. Standart olmasaydı faiz gelirini 1.890 TL yerine 1.260 TL olarak dikkate almamız gerekecekti.

Mahsup işlemi yapıldıktan sonra kalan tutarın müşteri firma Bilgin Koltuk Üretim A.Ş. 'ye ödenmesi,

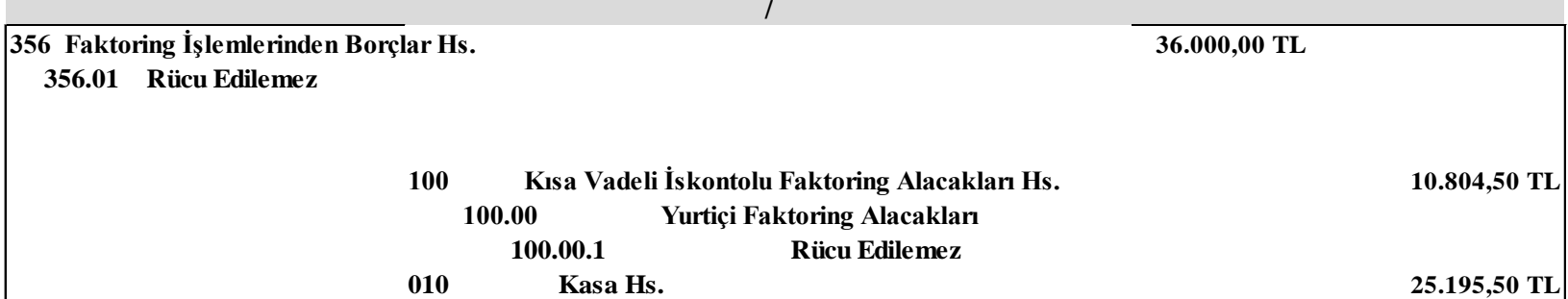


Vade sonunda BAŞ Faktoring A.Ş. alacakları ABC A.Ş.'den tahsil ettiğinde,

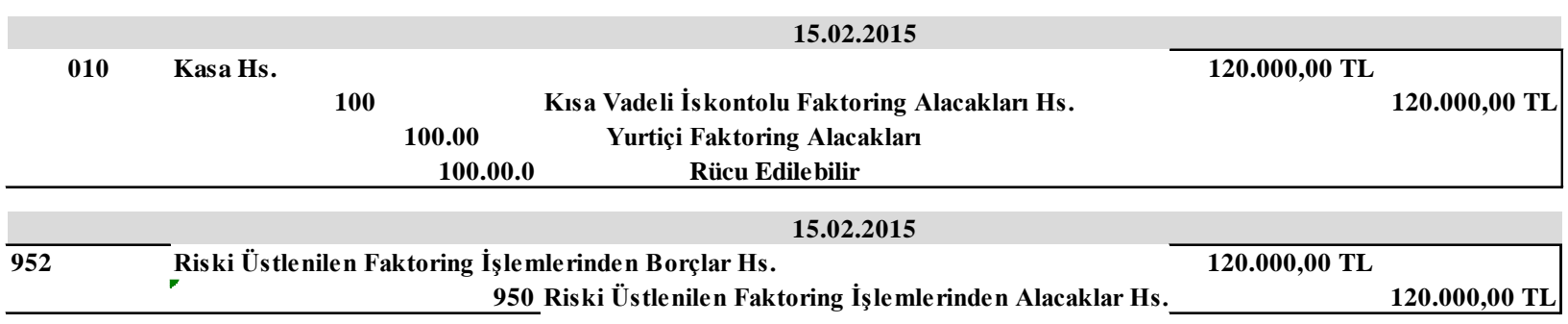

İlgili muhasebe kayıtlarında faktoring şirketlerinin müşterileriyle yaptıkları faktoring sözleşmeleri ile bu sözleşmelere ilişkin olarak düzenlenen diğer kağıtların damga vergisinden istisna olması sebebiyle Damga Vergisi hesaplanmamıştır. Buna ilaveten yapılan işlemin rücu edilemez faktoring işlemi olması sebebiyle vade sonunda alacakları ABC A.Ş.'den tahsil edilemeseydi faktoring şirketinin alacaklarını devraldığı Bilgin Koltuk Üretim A.Ş.'ye rücu etmeye hakkı yoktur. Dolayısıyla alacak şüpheli hale gelmiş sayılır.

\begin{tabular}{|c|c|c|c|}
\hline \multirow{3}{*}{$\begin{array}{l}170 \\
\quad 170.00 .0 .0\end{array}$} & \multicolumn{3}{|c|}{ I } \\
\hline & Tasfiye Olunacak Alacaklar Hs. & & $120.000,00 \mathrm{TL}$ \\
\hline & \multicolumn{3}{|l|}{ Yasal Takip müşterisi } \\
\hline & 100 & Kısa Vadeli İskontolu Faktoring Alacakları Hs. & \multirow[t]{3}{*}{$120.000,00 \mathrm{TL}$} \\
\hline & 100.00 & Yurtiçi Faktoring Alacaklanı & \\
\hline & 100.00 .1 & Rücu Edilemez & \\
\hline
\end{tabular}

Faktoring Şirketlerinde Şüpheli Ticari alacak karşılıkları BDDK yönetmelik hükümleri gereğince düzenlenmiştir. Şüpheli alacak kriterlerini taşıyan alacaklar 170 hesap grubunda "Tasfiye Olunan Alacaklar" hesabına aktarılır ve yine aynı yönetmelik hükümleri gereğince bu alacaklar için özel karşılık ayrılır. (180-Özel Karşılıklar)

\begin{tabular}{|c|c|c|c|}
\hline & & I & \\
\hline 820 & Karşılık ve De ğer Düşme Giderleri & & $120.000,00 \mathrm{TL}$ \\
\hline 820.00 .0 .0 & Özel Karşılık Gide rle ri & & \\
\hline & 180 & Özel Karşıılıklar & $120.000,00 \mathrm{TL}$ \\
\hline
\end{tabular}

İlgili uygulamada anapara ve faizin vadesinden önce ödenmesi gereken tarihten itibaren tahsilinin bir yılı geçmiş olması varsayımı altında özel karşılık kaydı atılmıştır.

\section{Sonuç}

İşletmeler gelişen ve küreselleşen rekabet ortamında güvenilir, karşılaştırılabilir, anlaşılabilir ve ortak bir dili ifade eden muhasebe standartlarını kullanmaktadır. Muhasebe standartları ile saptayabileceğimiz işletmenin değeri işletmenin karlılığı ile doğru orantılıdır. Karlılı̆̆ oluşturan en önemli unsur ise hasılattır.

Hasılat standardında iki önemli husus esas alınmaktadır. Bunlardan birincisi dönemsellik esası, diğeri ise tahakkuk ilkesidir. Dönemsellik ilkesi gereği gelir ve giderin aynı dönemde muhasebeleştirilmesi gerekmektedir. Tahakkuk ilkesi kapsamında işlem ve olaylar ödemelerin yapıldığı tarih itibarıyla değil bunların gerçekleştiği tarih esas alınarak mali tablolara yansıtılmalıdır.

Çalışmanın amacı Faktoring Şirketlerinin elde ettiği gelir getirici unsurlarının 18 Nolu Türkiye Muhasebe Standardı çerçevesinde (TMS 18 "Hasılat") analiz edilmiş olunup, olması gereken muhasebe kayıtları ve mahiyetleri açıklanmıştır.

Sonuç olarak, TMS 18 standardı öncesi uygulamada farklılıklar olmakla birlikte standardın gelmesi ile beraber faktoring şirketlerinde işlemin vadeli veya vadesiz olması durumunda vadeli satışlardaki gelirin içerisinde yer alan faiz gelirinin ayrıştırılıp gerçek satış bedelinin bulunması ve ait olduğu dönemde muhasebeleşmesi gerekmektedir. Buna ilaveten standarda göre mal satışında satış bedeli gerçeğe uygun değeri ile muhasebeleşmeli ve gelir kaydedebilmek için riskin ve malın mülkiyetinin alıcıya devredilmesi gerekmekte olup, devredilmediği durumda gelir tahakkuku yapılamamaktadır. Faktoring şirketlerinin genelde vadeli çalışması sebebiyle ilgili çalışmada vadeli satışlara ilişkin örnekler üzerinden açıklamalar ve ulaşılan sonuçlara yer verilmiştir. 


\section{KAYNAKÇA}

http://www.resmigazete.gov.tr/eskiler/2012/12/20121213-1.htm, Erişim Tarihi: 13.03.2016

http://faktoringdernegi.org.tr/faktoring/isleyis, Erişim Tarihi: 6.3.2016

http://www.mevzuat.gov.tr/Metin1.Aspx?MevzuatKod=1.5.6098\&sourceXmlSearch=\&Mevzuatlliski=0\&Tertip=5\&Tur=1\&No=6098, Erişim Tarihi: 7.3.2016

http://gib.gov.tr/gibmevzuat, Erişim Tarihi: 7.3.2016

http://www.gib.gov.tr/fileadmin/mevzuatek/eski/damgavertum2tarife.html, Erişim Tarihi: 7.3.2016

http://www.resmigazete.gov.tr/eskiler/2008/12/20081205-13.htm, Erişim Tarihi: 7.3.2016

http://www.gib.gov.tr/node/88934,Erişim Tarihi: 7.3.2016

http://kgk.gov.tr/contents/files/TMS18.pdf, Erişim Tarihi: 7.3.2016

https://www.bddk.org.tr/websitesi/turkce/Mevzuat/FinansalK Faktoring Finansman Kanunu/11493finansal kiralama kanunu 19.12 .201 2.pdf, Erişim Tarihi: 13.03.2016

Aygün, R. (2012), Örnek ve Açıklamalarla TMS 18 Hasılat Standardı. Vergi Dünyası Dergisi, 4(368), 96-109.

Yücenurşen, M. , Peker, A.A. , Apak, İ. , Polat, Y. ,TMS 18 Hasılat Standardı Çerçevesinde Hasılatın Muhasebeleştirilmesi ve Özellik arz eden Durumlar. , Aksaray Üniversitesi İktisadi ve İdari Bilimler Fakültesi Dergisi, 6(2), 1-8.

Sağlam, N. , Yolcu, M. , Faktoring Şirketlerinde Finansal Raporlama, İstanbul: Beta: 3-5.

Özerhan, Y. , Yanık, S. , TMS TFRS, İstanbul: TÜRMOB Yayınları : 114-117.

Akbult, A. , Karşılaştırılmalı TMS/TFRS-Vergi Uygulamaları ve Sonuçları, İstanbul: Maliye Hesap Uzmanları Derneği: $1213-1219$ 